University of Wollongong

Research Online

Faculty of Engineering and Information

Faculty of Engineering and Information

Sciences - Papers: Part B

Sciences

2017

\title{
Influence of relaxation modes on membrane fouling in submerged membrane bioreactor for domestic wastewater treatment
}

\author{
Rasikh Habib \\ University of Engineering and Technology \\ Muhammad Bilal Asif \\ University of Wollongong, University of Engineering and Technology, mba409@uowmail.edu.au \\ Sidra Iftekhar \\ University of Engineering and Technology, Lappeenranta University of Technology, Finland \\ Zahiruddin Khan \\ Punjab Saaf Pani Company \\ Khum Gurung \\ Lappeenranta University of Technology, Finland
}

See next page for additional authors

Follow this and additional works at: https://ro.uow.edu.au/eispapers1

Part of the Engineering Commons, and the Science and Technology Studies Commons

Research Online is the open access institutional repository for the University of Wollongong. For further information contact the UOW Library: research-pubs@uow.edu.au 


\title{
Influence of relaxation modes on membrane fouling in submerged membrane bioreactor for domestic wastewater treatment
}

\author{
Abstract \\ Relaxation and backwashing have become an integral part of membrane bioreactor (MBR) operations for \\ fouling control. This study was carried out on real municipal wastewater to evaluate the influence of \\ different operational strategies on membrane fouling at equivalent water yield. Four relaxation modes \\ $\left(\mathrm{MBR}_{10+0}, \mathrm{MBR}_{10+1}, \mathrm{MBR}_{10+1.5}\right.$ and $\left.\mathrm{MBR}_{10+2}\right)$ were tested to analyze membrane fouling behavior. For the \\ optimization of relaxation modes, fouling rate in terms of trans-membrane pressure, hydraulic resistances \\ and characteristics of fouling fractions were analyzed. It has been observed that cake layer resistance \\ was minimum in $\mathrm{MBR}_{10+1.5}$ but pore blockage resistance was increased in all relaxation modes. \\ Moreover, high instantaneous flux contributed significantly to fouling rate at the initial stage of MBR \\ operations. Relaxation modes were also efficient in removing irreversible fouling to some extent. Under all \\ relaxation modes, COD removal efficiency ranged from 92 to $96.5 \%$. Ammonium and TP removal were on \\ the lower side due to the short solids and hydraulic retention time. \\ Disciplines \\ Engineering | Science and Technology Studies

\section{Publication Details} \\ Habib, R., Asif, M., Iftekhar, S., Khan, Z., Gurung, K., Srivastava, V. \& Sillanpää, M. (2017). Influence of \\ relaxation modes on membrane fouling in submerged membrane bioreactor for domestic wastewater \\ treatment. Chemosphere, 181 19-25.

\section{Authors} \\ Rasikh Habib, Muhammad Bilal Asif, Sidra Iftekhar, Zahiruddin Khan, Khum Gurung, Varsha Srivastava, \\ and Mika Sillanpää
}




\title{
Influence of relaxation modes on membrane fouling in submerged membrane bioreactor for domestic wastewater treatment
}

\section{(Accepted Manuscript)}

\author{
Rasikh Habib $^{1 \$}$, Muhammad Bilal Asif ${ }^{1,2 \$}$, Sidra Iftekhar ${ }^{1,3 *}$, Zahiruddin Khan ${ }^{4}$, Khum \\ Gurung $^{3}$, Varsha Srivastava ${ }^{3}$, Mika Sillanpää ${ }^{3,5}$ \\ ${ }^{1}$ Department of Environmental Engineering, University of Engineering \& Technology, Taxila- \\ 47050, Pakistan. \\ 2 Strategic Water Infrastructure Laboratory, School of Civil, Mining and Environmental \\ Engineering, University of Wollongong (UOW), NSW 2522, Australia. \\ ${ }^{3}$ Laboratory of Green Chemistry, School of Engineering Science, Lappeenranta University of \\ Technology, Sammonkatu 12, FI-50130 Mikkeli, Finland. \\ ${ }^{4}$ Punjab Saaf Pani Company, Govt. of Punjab, Lahore (54000), Pakistan \\ ${ }^{5}$ Department of Civil and Environmental Engineering, Florida International University, Miami, \\ FL-33174, USA. \\ $\$$ these authors contributed equally to this work. \\ *Corresponding Author (Email: sidra_iftekhar@yahoo.com, sidra.iftekhar@lut.fi)
}

\section{Publication details:}

Habib, R., Asif, M.B., Iftekhar, S., Khan, Z., Gurung, K., Srivastava, V., Sillanpää, M. 2017. Influence of relaxation modes on membrane fouling in submerged membrane bioreactor for domestic wastewater treatment. Chemosphere, 181, 19-25. 


\section{Highlights}

- Relaxation was effective for membrane fouling control

- High instantaneous flux contributed significantly to fouling at initial stages.

- Relaxation modes were efficient in removing irreversible fouling to some extent.

- 10 min filtration and 1.5 min relaxation mode was the most efficient scenario.

- Similar characteristics of foulants on membrane surface and in bulk MBR 


\begin{abstract}
:
Relaxation and backwashing have become an integral part of membrane bioreactor (MBR) operations for fouling control. This study was carried out on real municipal wastewater to evaluate the influence of different operational strategies on membrane fouling at equivalent water yield. Four relaxation modes $\left(\mathrm{MBR}_{10+0}, \mathrm{MBR}_{10+1}, \mathrm{MBR}_{10+1.5}\right.$ and $\left.\mathrm{MBR}_{10+2}\right)$ were tested to analyze membrane fouling behavior. For the optimization of relaxation modes, fouling rate in terms of trans-membrane pressure, hydraulic resistances and characteristics of fouling fractions were analyzed. It has been observed that cake layer resistance was minimum in $\mathrm{MBR}_{10+1.5}$ but pore blockage resistance was increased in all relaxation modes. Moreover, high instantaneous flux contributed significantly to fouling rate at the initial stage of MBR operations. Relaxation modes were also efficient in removing irreversible fouling to some extent. Under all relaxation modes, COD removal efficiency ranged from $92-96.5 \%$. Ammonium and TP removal were on the lower side due to the short solids and hydraulic retention time.
\end{abstract}

Keywords: Fouling resistances; membrane fouling rate; relaxation modes; soluble microbial products; submerged membrane bioreactor

\title{
1. INTRODUCTION
}

Various regions of the world are facing unprecedented burdens in terms of water availability due to rapid population growth and urbanization (Zimmerman et al., 2008). Approximately 700 million people are under water stress conditions. To deal with water scarcity issues, water reuse practices are required to be adopted. For advanced wastewater treatment and reuse, the membrane technology, especially membrane bioreactor (MBR), is the most evolving technique over the past few decades (Cho et al., 2011; Malaeb et al., 2013). Operations of MBR are similar 
to conventional wastewater treatment process but separation by low pressure driven membrane differentiates it from the activated sludge treatment (Jahangir et al., 2012; Leyva-Diaz et al., 2015).

The membrane bioreactor is now well established treatment technology for both domestic and industrial wastewater because of high effluent quality, extended sludge retention time (SRT), low sludge production, high mixed liquor suspended solid (MLSS) concentration, high nutrient removal, and low area constraints (Cho and Fane, 2002; Judd, 2008; Cho et al., 2011; Deng et al., 2014). However, fouling of membrane is the major limitation in the widespread application of MBR (Guo et al., 2012). Sludge mixed liquor is the main cause of membrane fouling as the foulants instigate from MLSS (Wu et al., 2006). Therefore, several factors can affect membrane fouling propensity (Guo et al., 2012).

The mixed liquor can disturb the filterability of membrane by influencing the viscosity (Itonaga et al., 2004), extracellular polymeric substances (EPS) (Cho and Fane, 2002) and cell debris (Kim et al., 2014). Other factors affecting membrane fouling are operational conditions (such as aeration intensity, HRT, SRT, flux and frequency of backwashing) and physicochemical characteristics of membranes (Yigit et al., 2010). Fouling, which leads to membrane cleaning and finally replacement of membranes, results in high trans-membrane pressure (TMP) and low flux and disrupts the MBR operations frequently. Membrane fouling takes place due to the formation of cake layer and blockage of pores. Pore blockage is dominant at initial stages of the operation, when the membrane is new but the cake layer formation takes over in the later stages of operation (Nguyen et al., 2013; Akhondi et al., 2014; Kurita et al., 2014). 
Despite of the high quality output of MBR, further improvements are still required to develop operational strategies to achieve best possible performance. Many researchers have tried to correlate membrane fouling with various membrane materials and operational conditions. Dvořák et al. (2011) examined the influence of different operating conditions on the performance of pilot scale submerged MBR and found that EPS formation results in rapid membrane fouling. Fu et al. (2012) reported that aeration rate and time has a positive influence over membrane fouling and effluent quality. Similarly, Lim et al. (2007) evaluated the impacts of operational parameters on aeration on/off time in MBR and observed that MLSS concentration and EPS components are influenced by aeration time. EPS components increase with increase in relaxation time of aeration. In a recent study by Campo et al. (2017), effect of EPS on membrane fouling and foaming was thoroughly investigated in MBR at three different aerated regimes, expressed as $\mathrm{t}_{\text {aeration }} / \mathrm{t}_{\text {cycle, }}$ i.e., (i) $60 \mathrm{~min} / 180 \mathrm{~min}$; (ii) $80 \mathrm{~min} / 180 \mathrm{~min}$ and (iii) $30 \mathrm{~min} / 90 \mathrm{~min}$. They observed rapid membrane fouling and relatively higher EPS production in the first two aerated regimes having less number of cycles per day (Campo et al., 2017). Since EPS plays an important role in membrane fouling, a number of strategies to control EPS generation have been reviewed extensively by Lin et al. (2014). Maqbool et al. (2014) investigated the performance of submerged MBR for the treatment of synthetic wastewater under different filtration modes and reported that the short/frequent filtration time reduced the membrane fouling. Jiang et al. (2005) examined different scenarios of backwashing and reported that less frequent but longer backwashing provide better fouling control. Most of the research has been carried out on synthetic wastewater (Jiang et al., 2005; Maqbool et al., 2014) which is the main hurdle in the applicability of these studies as the synthetic wastewater composed of readily degradable soluble organics i.e., glucose (Maqbool et al., 2014) is mainly used to serve as soluble COD. The 
composition of real wastewater is much more diverse due to the presence of readily degradable organics, slowly degradable organics and non-degradable organics both in soluble and insoluble form (Metcalf et al., 1991). Furthermore, the colloidal particles, both organic and inorganic, in real wastewater are responsible for pore blockage at the initial stage of the MBR operations. This phenomenon of pore blockage due to colloidal particles is absent in the MBR operations with synthetic wastewater. Therefore, effectiveness of different operating conditions, especially relaxation time, is yet to be optimized for real wastewater. Relaxation, also known as temporary cessation or pausing, allow the foulants to move away from the membrane surface to the mixed liquor via concentration gradient (Wang et al., 2014). Intermittent relaxation allows for stable operation even above critical flux and high flux can be maintained for longer period of time. Relaxation is preferred over backwashing as backwashing with permeate causes pore blockage in membrane (Wu et al., 2008).

This study was aimed to elucidate the influence of various relaxation modes on hydraulic performance, fouling rate, characteristics of fouling fractions and performance of MBR for the treatment of real wastewater.

\section{EXPERIMENTAL}

\subsection{Experimental setup}

To provide uniform characteristics of actual wastewater, all relaxation modes were executed simultaneously. So, four lab scale aerobic MBRs with working volume of $30 \mathrm{~L}$ each were operated for 21 days (Fig 1). Primary sedimentation (60 min) was also provided before the introduction of wastewater in bioreactor. Each tank was equipped with submerged PVDF hollow

fiber membrane (Hinada, China) having pore size of $0.1 \mu \mathrm{m}$ with filtration area of $0.8 \mathrm{~m}^{2}$. The 
flux was kept at $12 \mathrm{~L} / \mathrm{m}^{2} / \mathrm{h}(\mathrm{LMH})$ to setup the hydraulic retention time (HRT) of $4.0 \mathrm{hrs}$. Mixed liquor suspended solid concentration (MLSS) was maintained between 9-10 g/L by wasting sludge on regular basis, corresponding to a solids retention time (SRT) of 12 days. Air diffusers were used in each type of MBR to maintain dissolved oxygen concentration above $3.5 \mathrm{mg} / \mathrm{L}$. Mechanical mixer was also used to completely mix the contents of real wastewater. Each type of MBR was operated at an average temperature of $20{ }^{\circ} \mathrm{C}$ and trans-membrane pressure (TMP) was continuously measured by digital data logging manometer (Model 840086, Sper Scientific, USA). To maintain the permeate flux for each MBR; peristaltic pump (V-FLO, Model BT100M, China) was used.

Fig 1: (here)

\subsection{Wastewater analysis and characteristics}

Composite samples were taken from screened raw wastewater for the determination of wastewater characteristics on daily basis. Total suspended solids (TSS), total solids (TS), total dissolved solids (TDS), biological oxygen demand $\left(\mathrm{BOD}_{5}\right)$, chemical oxygen demand (COD) total nitrogen $(\mathrm{TN})$, total phosphorous $(\mathrm{TP})$, ammonium nitrogen $\left(\mathrm{NH}_{4}{ }^{+}-\mathrm{N}\right)$ and $\mathrm{pH}$ were measured as per the procedure outlined in Standard Method (APHA et al., 2005). Grab samples were taken from membrane tank for the analysis of mixed liquor suspended solids (MLSS) and mixed liquor volatile suspended solids (MLVSS), specific oxygen uptake rate was measured by digital dissolved oxygen meter (Model 8403, PROLABMAS, Indonesia) as per the procedure outlined in Standard Method (APHA et al., 2005). Wastewater characteristics are summarized in Table 1. 
Seed sludge was collected from full scale sewage treatment plant (Sector I-9, Islamabad, Pakistan) and acclimatized for the period of one month to get MLSS concentration of 9-10 g/L.

Table 1: (here)

\subsection{Relaxation experiment}

Three relaxation modes and one continuous mode were tested till the fouling of membrane (Table 2). Net water productivity for each mode was equivalent to an average flux of $12 \mathrm{LMH}$ with the deviation of less than $1 \%$. Intrinsic membrane resistance $\left(\mathrm{R}_{\mathrm{m}}\right)$ was measured using clean water tests for each mode. Average deviation in intrinsic membrane resistance $\left(\mathrm{R}_{\mathrm{m}}\right)$ was found to be less than 5\%. Total filtration resistance $\left(\mathrm{R}_{\mathrm{t}}\right)$ was determined (Eq. 1), where dTMP is change in trans-membrane pressure, $\mathrm{J}$ is permeate flux and $\mu_{20}{ }^{\circ} \mathrm{C}$ is dynamic fluid viscosity at $20{ }^{\circ} \mathrm{C}$. Dynamic fluid viscosity was adjusted with the relationship given in Eq. 2, where the value of $\Theta$ is 1.033 and 1.025 for $4{ }^{\circ} \mathrm{C}<\mathrm{T}<20{ }^{\circ} \mathrm{C}$ and $\mathrm{T}=20{ }^{\circ} \mathrm{C}$ respectively.

$$
\begin{gathered}
R_{t}=\frac{d T M P}{J \times \mu_{20^{\circ} \mathrm{C}}} \\
\mu_{20^{\circ} \mathrm{C}}=\mu_{T^{\circ} \mathrm{C}} \times \theta^{20-T}
\end{gathered}
$$

Since each relaxation mode was tested twice, membrane was cleaned using three step protocols: (i) cleaning with $40 \mathrm{~mL}$ ultra-pure water (ii) backwashing with $40 \mathrm{~mL}$ ultra-pure water at a flux of $30 \mathrm{LMH}$ (iii) desorbing in $2 \% \mathrm{NaOH}$ solution with effective chlorine strength of $2.5 \mathrm{~g} / \mathrm{L}$ for 12 hours. The fouling layers were separated in three fractions of resistance i.e., cake layer, pore blockage and intrinsic membrane resistance. Clean water test for the determination of the resistance of each fraction was carried out after each step. These three fractions were also evaluated for extractable or bound extracellular polymeric substances (eEPS), MLSS, soluble 
microbial products (SMP), carbohydrate and proteins concentrations. Centrifuged cleaning solutions at $2000 \mathrm{rpm}$ were used to isolate suspended solids from supernatant. Filtered supernatant was then used for the analysis of SMP. Heating method was used for the extraction of eEPS (Ge et al., 2007). Characterization of SMP and eEPS were carried out based on their dissolved organic carbon (DOC), carbohydrate and protein concentrations. Lowry method and phenol-sulfuric acid method were used for the measurement of proteins and polysaccharides, respectively (Lowry et al., 1951; Dubois et al., 1956; Peterson, 1977).

Table 2: (here)

\section{RESULTS AND DISCUSSION}

\subsection{Hydraulic Performance of Relaxation modes}

All four relaxation modes exhibited significant variation in temporal TMP profile (Fig 2). It was also observed that $\mathrm{MBR}_{10+1}$ and $\mathrm{MBR}_{10+1.5}$ presented lower fouling than $\mathrm{MBR}_{10+0}$ and $\mathrm{MBR}_{10+2}$ at the end of each operational mode i.e. maturation (3-6 kPa), steady (6-9 kPa) and TMP jump (9-30 $\mathrm{kPa})$ phase. Steady phase period for $\mathrm{MBR}_{10+1.5}$ was longer with rapid TMP increase at the end. It took $5.25,8.25,10.25$ and 7.5 days by each membrane on average to foul in $\mathrm{MBR}_{10+0}$, $\mathrm{MBR}_{10+1}, \mathrm{MBR}_{10+1.5}$ and $\mathrm{MBR}_{10+2}$, respectively. Similar results were obtained in each membrane module when normalized with instantaneous flux. It can also be established that because of high instantaneous flux membrane fouling is insignificant as average flux is reported to be significant for the determination of fouling rates (Gander et al., 2000; Liao et al., 2004). The comparison of all four relaxation modes indicates (Fig. 2) that the overall filtration duration for $\mathrm{MBR}_{10+1.5}$ was longer as compared to other options and decreased with the increase in relaxation time which is inconsistent with the findings of $\mathrm{Wu}$ et al. (2008) who reported that the relaxation duration 
showed no effect on TMP as much as filtration interval. This inconsistency in results may be due to the difference in characteristics of synthetic wastewater used by $\mathrm{Wu}$ et al. (2008), however, real wastewater was used in this study.

Fig 2: (here)

For the determination of fouling rates, aeration was also turned off for each relaxation mode. Fouling rates determined for first hour of operation, maturation phase, steady phase and TMP jump phase in $\mathrm{MBR}_{10+0}, \mathrm{MBR}_{10+1}, \mathrm{MBR}_{10+1.5}$ and $\mathrm{MBR}_{10+2}$ are shown in Fig 3. $\mathrm{MBR}_{10+0}$ compared to other relaxation modes demonstrated the lowest fouling rate (i.e., $2.5 \mathrm{kPa} / \mathrm{day}$ ) after the first hour of operation, indicating that higher instantaneous due to relaxation timed strongly influenced the initial fouling rates. However, the fouling rates started to decrease with the increase in filtration time and at the end of each experiment, fouling rates in all relaxation modes were lower than that of continuous mode. During the maturation, steady, and TMP jump phase, the lowest fouling rates of $3.69,0.82$, and $4.58 \mathrm{kPa} / \mathrm{day}$, respectively were obtained for $\mathrm{MBR}_{10+1.5}$, whereas $\mathrm{MBR}_{10+2}$ featured highest fouling rates in each phase. Conventionally, long filtration and short relaxation intervals were helpful in reducing fouling rates but not useful for hindering TMP increase during filtration (Hong et al., 2002). Therefore, filtration and relaxation intervals needs to be adjusted carefully to reduce fouling resistances and retard TMP increase during relaxation -filtration cycles.

Fig 3: (here)

\subsection{Evaluation of fouling fractions}

Total hydraulic resistances $\left(\mathrm{R}_{\mathrm{t}}\right)$ were determined for each fraction (i.e., cake layer, pore blockage and intrinsic membrane resistance) after the fouling of membrane module, in all four relaxation 
modes. It is clear from Table 3 that cake layer resistance contributed more to the total resistance than pore blockage and intrinsic membrane resistances. It also exhibits that relaxation modes were efficient to control fouling by reducing the compression of cake layer. From Table 3, it can be resolved that fouling was controlled by relaxation even when the net water yield is identical to that of continuous mode. In addition, contribution of each fouling fractions was observed to be different in each relaxation mode. Compared to other relaxation modes, cake layer resistance was minimum in $\mathrm{MBR}_{10+1.5}$. However, pore blockage resistance was increased in all relaxation modes. Since the duration of this study is short, it is not possible to elucidate the effects of enhanced pore blockage resistance on membrane fouling.

Table 3: (here)

The fouling layers were collected after rinsing, backwashing and desorbing the membrane modules after each relaxation mode and were assessed. Fraction collected after rinsing the membrane module is generally comprised of biopolymers and sludge flocs (Hong et al., 2014). $\mathrm{MBR}_{10+0}$ contained the highest suspended solid (SS) concentration of $3.5 \mathrm{~g} / \mathrm{m}^{2}$, SS concentration was less than less than $1.5 \mathrm{~g} / \mathrm{m}^{2}$ in all other relaxation modes. The lowest SS concentration (1.1 $\mathrm{g} / \mathrm{m}^{2}$ ) was observed in $\mathrm{MBR}_{10+1.5}$. However, SS concentrations in $\mathrm{MBR}_{10+1}\left(1.27 \mathrm{~g} / \mathrm{m}^{2}\right)$ and $\mathrm{MBR}_{10+2}\left(1.30 \mathrm{~g} / \mathrm{m}^{2}\right)$ were comparable. These results suggests that temporary cessation successfully reduced the concentration of foulants on membrane surface.

The backwashed and desorbed fractions collected after backwashing and desorbing were mainly composed of particles blocking the membrane pores and causing irreversible fouling, respectively. These fractions were assessed for SS concentration and it was found that SS were detectable only in backwashed fraction but not in desorbed fraction. SS concentration in 
backwashed fraction may also be undetectable in case of synthetic wastewater. SS concentrations in backwashed fraction for $\mathrm{MBR}_{10+0}, \mathrm{MBR}_{10+1}, \mathrm{MBR}_{10+1.5}$ and $\mathrm{MBR}_{10+2}$ were $0.5,0.25,0.1$ and $0.28 \mathrm{~g} / \mathrm{m}^{2}$, respectively.

SMP for fouling fractions were also analyzed in backwashed and desorbed fraction to elucidate the characteristics of foulants. SMP profile, in terms of their DOC, of each fouling fraction for all relaxation modes is given in Fig 4, indicating that SMP concertation was significantly reduced in rinsed fraction that mainly contains sludge flocs and gel layer as well as in desorbed fraction. In line with the findings of Jørgensen et al. (2014), SMP in all fouling fractions of $\mathrm{MBR}_{10+0}$ was greater than that of $\mathrm{MBR}_{10+1}, \mathrm{MBR}_{10+1.5}$ and $\mathrm{MBR}_{10+2}$. These results indicate that relaxation modes may not only move the foulants away from membrane surface but can also change the characteristics of fouling fractions. Hence, relaxation modes can be effective for the control of irreversible fouling to some extent.

Fig 4: (here)

\subsection{Evaluation of carbohydrate and protein ratio in SMP and eEPS}

The characteristics of cake layer should be similar to the mixed liquor of MBR because cake layer originates from the mixed liquor. In this regard, eEPS in the fouling fraction collected after rinsing the cake layer from membrane module following each relaxation mode i.e., $\mathrm{MBR}_{10+0}$, $\mathrm{MBR}_{10+1}, \mathrm{MBR}_{10+1.5}$ and $\mathrm{MBR}_{10+2}$ was measured. In line with findings of a short term study conducted by Wu et al. (2008), eEPS in the cake layer of each relaxation mode was ranged from 80-90 mg-DOC/g-SS. On the other hand, eEPS in the mixed liquor of MBR was found to be similar to that in rinsed fraction i.e., $75-95 \mathrm{mg}-\mathrm{DOC} / \mathrm{g}-\mathrm{SS}$., suggesting almost similar characteristics of foulants on membrane surface and in bulk MBR. However, different 
characteristics (e.g., particle size, eEPS and microbial community) of cake layer from mixed layer have been reported in some long term MBR studies (Gao et al., 2010; Lin et al., 2014). For example, Lin et al. (2011) observed 1.5 times higher EPS in cake layer than mixed liquor after operating an anaerobic MBR for 7 months. During long MBR operation, poor substrate availability to microbes at the lower part of cake layer and limited oxygen transfer as well as temporal and spatial variations can instigate cell lysis or decay, thereby increasing the concentration of EPS in cake layer (Hwang et al., 2008; Lin et al., 2014).

The properties of EPS and SMP have been reported to highly affect the rate of membrane fouling in MBR. Thus, SMP and eEPS for each fouling fraction were then evaluated for carbohydrates and proteins, expressed in terms of $\mathrm{C} / \mathrm{P}$ ratio, after each relaxation mode to further confirm the similarities in the characteristics of mixed liquor and cake layer as well as among the different fouling fractions. $\mathrm{C} / \mathrm{P}$ ratio for all fouling fractions as well as mixed liquor was less than 1 (Table 4), indicating higher concentration of proteins in SMP and eEPS compared to carbohydrates. Results of this study are in agreement with the literature (Liang et al., 2007; Lin et al., 2011). Depending on operating conditions (e.g., SRT) and substrate type, concentration of proteins can be higher in eEPS and SMP than carbohydrates due to the release of huge quantities of endoenzmyes via cell lysis. Moreover, proteins are generally hydrophobic and adsorb on to activated sludge, thereby constituting the main contents of eEPS (Sponza, 2002; Meng et al., 2006). On the other hand, contents of carbohydrates, particularly polysaccharides, are hydrophilic and readily biodegradable compared to proteins. Activated sludge can metabolize carbohydrate, reducing their concentration in eEPS and SMP (Massé et al., 2006; Lin et al., 2014). 
C/P ratio for SMP was 0.15 and 0.35 in backwashed and desorbed fractions, respectively (Table 4). These values for SMP were relatively lower than mixed liquor and rinsed cake layer fraction probably because carbohydrates may not pass through the membrane due to their higher molecular weight compared to proteins (Wu et al., 2008). C/P ratio for SMP and eEPS in mixed liquor and in rinsed fraction were almost identical, further confirming the similar characteristics of foulants in bulk MBR and cake layer. As explained earlier, characteristics of foulants in bulk MBR and cake layer may differ during long operation of MBR.

Table 4: (here)

\subsection{Treatment efficiencies}

Treatment efficiencies of COD, total nitrogen $(\mathrm{TN})$, ammonium $\left(\mathrm{NH}_{4}{ }^{+}-\mathrm{N}\right)$ and total phosphorous (TP) are presented in Fig 5. Treatment performances of each MBR were comparable with $\mathrm{MBR}_{10+0}$ which provided highest COD removal of $96.5 \%$. Under all relaxation modes, COD removal efficiency was ranged from $92-96.5 \%$.

MBR has the ability to operate at high MLSS concertation ( $>5 \mathrm{mg} / \mathrm{L})$ and can effectively retain slow-growing microorganisms in the bioreactor, thereby providing enhanced nutrient removal (Holakoo et al., 2007). Operational parameters (e.g. dissolved oxygen and SRT) can influence the growth of slow-growing microorganism, requiring anoxic, aerobic and anaerobic conditions for the removal of nitrogen and phosphorous (Pochana et al., 1999; Monclús et al., 2010). However, nitrogen removal can be possible in an intermittently aerated aerobic MBR (Guadie et al., 2014). In this study, $\mathrm{TN}$ removal in $\mathrm{MBR}_{10+0}, \mathrm{MBR}_{10+1}, \mathrm{MBR}_{10+1.5}$ and $\mathrm{MBR}_{10+2}$ was 79.2 , 83.7, 85.5 and $81.7 \%$, respectively. On other hand, ammonium $\left(\mathrm{NH}_{4}{ }^{+}-\mathrm{N}\right)$ removal in $\mathrm{MBR}_{10+0}$, 
$\mathrm{MBR}_{10+1}, \mathrm{MBR}_{10+1.5}$ and $\mathrm{MBR}_{10+2}$ was $44,59.3,65.7$ and $66.8 \%$, respectively, suggesting that longer relaxation periods supported the growth of ammonium-oxidizing bacteria. Since bacteria responsible for nitrogen removal are slow-growing, relatively low $\mathrm{TN}$ and ammonium removal was expected because MBRs were operated at a short SRT of 12 days in this study. In a recent study by Maqbool et al. (2014), 53-70\% ammonium removal was achieved in an MBR operated at a SRT of 20 days for the period of 15-25 days. In contrast, Holakoo et al. (2007) operated an MBR for than 6 months at 20 days SRT and achieved above 90\% ammonium removal, suggesting that duration of MBR operation in addition to SRT can also influence ammonium removal.

Phosphorus can be biologically removed through assimilation or luxury uptake by phosphorous accumulating organisms (PAOs) that are also a slow-growing microorganisms, preferably requiring anaerobic conditions for the uptake of phosphorus (Puig et al., 2008; Monclús et al., 2010). However, PAOs can also uptake phosphorous either in aerobic and anoxic conditions subject to the availability of nitrates (Mino et al., 1998). Operational parameters such as SRT, HRT and food to microorganism ratio can also influence the overall removal of phosphorous. For instance, Wang et al. (2015) observed that TP removal was reduced (25-30\%) by operating MBR at an HRT of $6 \mathrm{~h}$ compared to that operated at $8 \mathrm{~h}$ HRT. Similarly, TP removal in MBR was also reduced by 40-50\%, when the SRT of MBR was reduced from 40 to 20 days (Holakoo et al., 2007). In this study, TP removal in $\mathrm{MBR}_{10+0}, \mathrm{MBR}_{10+1}, \mathrm{MBR}_{10+1.5}$ and $\mathrm{MBR}_{10+2}$ was found to be $51.3,54.8,55.9$ and $56.4 \%$, respectively. Since each MBR was operated at short HRT and SRT of $4 \mathrm{~h}$ and 12 days, respectively, partial TP removal was expected. Moreover, the main objective of this study was to analyze the influence of relaxation modes on membrane fouling in MBR. 
Fig.5: (here)

\section{Conclusions}

In this study, performance of various operational parameters was evaluated for fouling control under different relaxation modes in membrane bioreactor (MBR) with equivalent water yield. Following major conclusions were obtained:

- $\mathrm{MBR}_{10+0}, \mathrm{MBR}_{10+1}, \mathrm{MBR}_{10+1.5}$ and $\mathrm{MBR}_{10+2}$ were fouled on average in 5.25, 8.25, 10.25 and 7.5 days, respectively. At initial stages of MBR operation, membrane fouling was strongly influenced by instantaneous flux.

- During the maturation, steady, and TMP jump phase, lowest fouling rates of 3.69, 0.82, and $4.58 \mathrm{kPa} / \mathrm{day}$ were obtained for $\mathrm{MBR}_{10+1.5}$, and $\mathrm{MBR}_{10+2}$ featured highest fouling rates in each phase. Similarly, total hydraulic resistance was found to be the lowest for $\mathrm{MBR}_{10+1.5}$.

- Membrane fouling could be controlled by optimizing the relaxation duration, since relaxation has a net positive effect even when the system was run at higher flux to generate constant water productivity.

- Different relaxation modes were also efficient for irreversible fouling control to some extent as $\mathrm{SMP}$ concentration in $\mathrm{MBR}_{10+0}$ was found to be higher than $\mathrm{MBR}_{10+1}, \mathrm{MBR}_{10+1.5}$ and $\mathrm{MBR}_{10+2}$

- Average eEPS (80-90 mg-DOC/g-SS) in rinsed fraction was similar to the mixed liquor (75$95 \mathrm{mg}-\mathrm{DOC} / \mathrm{g}-\mathrm{SS}$ ) obtained from bulk MBR which suggests similar characteristics of foulants on membrane surface and those in bulk MBR.

- Under all relaxation modes, COD removal efficiency ranged from $92-96.5 \%$. Ammonium and TP removal were relatively low because each MBR was operated at short SRT and HRT. 


\section{Acknowledgement}

The authors are thankful to the financial support provided by University of Engineering \&

Technology, Taxila under faculty research projects.

\section{References}

Akhondi, E., Wicaksana, F., Fane, A.G., 2014. Evaluation of fouling deposition, fouling reversibility and energy consumption of submerged hollow fiber membrane systems with periodic backwash. Journal of Membrane Science 452, 319-331.

APHA, AWWA, WEF, 2005. Standard Methods for the Examination of Water and Wastewater, 21st ed. American Public Health Association, Washington, DC.

Campo, R., Capodici, M., Di Bella, G., Torregrossa, M., 2017. The role of EPS in the foaming and fouling for a MBR operated in intermittent aeration conditions. Biochemical Engineering Journal 118, 41-52.

Cho, B., Fane, A., 2002. Fouling transients in nominally sub-critical flux operation of a membrane bioreactor. Journal of membrane science 209, 391-403.

Cho, Y.-H., Sibag, M.L., Eusebio, R.C., Kim, H.-S., 2011. Effect of organic loading on the performance of MBR for advanced treatment and water reuse. Desalination and Water Treatment 33, 224-230.

Deng, L., Guo, W., Ngo, H.H., Zhang, J., Liang, S., Xia, S., Zhang, Z., Li, J., 2014. A comparison study on membrane fouling in a sponge-submerged membrane bioreactor and a conventional membrane bioreactor. Bioresource technology 165, 69-74.

Dubois, M., Gilles, K.A., Hamilton, J.K., Rebers, P., Smith, F., 1956. Colorimetric method for determination of sugars and related substances. Analytical chemistry 28, 350-356.

Dvořák, L., Gómez, M., Dvořáková, M., Růžičková, I., Wanner, J., 2011. The impact of different operating conditions on membrane fouling and EPS production. Bioresource technology 102, 6870-6875.

Fu, H.-Y., Xu, P.-C., Huang, G.-H., Chai, T., Hou, M., Gao, P.-F., 2012. Effects of aeration parameters on effluent quality and membrane fouling in a submerged membrane bioreactor using Box-Behnken response surface methodology. Desalination 302, 33-42.

Gander, M., Jefferson, B., Judd, S., 2000. Aerobic MBRs for domestic wastewater treatment: a review with cost considerations. Separation and purification Technology 18, 119-130.

Gao, D.-W., Zhang, T., Tang, C.-Y.Y., Wu, W.-M., Wong, C.-Y., Lee, Y.H., Yeh, D.H., Criddle, C.S., 2010. Membrane fouling in an anaerobic membrane bioreactor: differences in relative abundance of bacterial species in the membrane foulant layer and in suspension. Journal of Membrane Science 364, 331-338.

Ge, L., Deng, H., Wang, H., Ma, L., Liu, Y., 2007. Comparison of extraction methods for quantifying extracellular polymers in activated sludges. Fresenius Environmental Bulletin 16, 299-303.

Guadie, A., Xia, S., Zhang, Z., Zeleke, J., Guo, W., Ngo, H.H., Hermanowicz, S.W., 2014. Effect of intermittent aeration cycle on nutrient removal and microbial community in a fluidized bed reactormembrane bioreactor combo system. Bioresource technology 156, 195-205.

Guo, W., Ngo, H.-H., Li, J., 2012. A mini-review on membrane fouling. Bioresource technology 122, 2734.

Holakoo, L., Nakhla, G., Bassi, A.S., Yanful, E.K., 2007. Long term performance of MBR for biological nitrogen removal from synthetic municipal wastewater. Chemosphere 66, 849-857.

Hong, H., Zhang, M., He, Y., Chen, J., Lin, H., 2014. Fouling mechanisms of gel layer in a submerged membrane bioreactor. Bioresource technology 166, 295-302. 
Hong, S., Bae, T., Tak, T., Hong, S., Randall, A., 2002. Fouling control in activated sludge submerged hollow fiber membrane bioreactors. Desalination 143, 219-228.

Hwang, B.-K., Lee, W.-N., Yeon, K.-M., Park, P.-K., Lee, C.-H., Chang, i.-S., Drews, A., Kraume, M., 2008. Correlating TMP increases with microbial characteristics in the bio-cake on the membrane surface in a membrane bioreactor. Environmental science \& technology 42, 3963-3968.

Itonaga, T., Kimura, K., Watanabe, Y., 2004. Influence of suspension viscosity and colloidal particles on permeability of membrane used in membrane bioreactor (MBR). Water Science and Technology 50, 301309.

Jahangir, D., Oh, H.-S., Kim, S.-R., Park, P.-K., Lee, C.-H., Lee, J.-K., 2012. Specific location of encapsulated quorum quenching bacteria for biofouling control in an external submerged membrane bioreactor. Journal of Membrane Science 411, 130-136.

Jiang, T., Kennedy, M., Guinzbourg, B., Vanrolleghem, P.A., Schippers, J., 2005. Optimising the operation of a MBR pilot plant by quantitative analysis of the membrane fouling mechanism. Water Science and Technology 51, 19-25.

Jørgensen, M.K., Keiding, K., Christensen, M.L., 2014. On the reversibility of cake buildup and compression in a membrane bioreactor. Journal of Membrane Science 455, 152-161.

Judd, S., 2008. The status of membrane bioreactor technology. Trends in biotechnology 26, 109-116.

Kim, E.-H., Dwidar, M., Kwon, Y.-N., Mitchell, R.J., 2014. Pretreatment with alum or powdered activated carbon reduces bacterial predation-associated irreversible fouling of membranes. Biofouling 30, 12251233.

Kurita, T., Kimura, K., Watanabe, Y., 2014. The influence of granular materials on the operation and membrane fouling characteristics of submerged MBRs. Journal of Membrane Science 469, 292-299.

Leyva-Diaz, J., Martin-Pascual, J., Fenice, M., Munio, M., Poyatos, J., 2015. Comparison between membrane bioreactor, a hybrid moving bed biofilm reactor-membrane bioreactor and a pure moving bed biofilm reactor-membrane bioreactor on membrane fouling. Journal of Environmental Protection and Ecology 16, 1502-1508.

Liang, S., Liu, C., Song, L., 2007. Soluble microbial products in membrane bioreactor operation: behaviors, characteristics, and fouling potential. Water Research 41, 95-101.

Liao, B., Bagley, D., Kraemer, H., Leppard, G., Liss, S., 2004. A review of biofouling and its control in membrane separation bioreactors. Water Environment Research 76, 425-436.

Lim, B., Choi, B., Yu, S., Lee, C., 2007. Effects of operational parameters on aeration on/off time in an intermittent aeration membrane bioreactor. Desalination 202, 77-82.

Lin, H., Liao, B.-Q., Chen, J., Gao, W., Wang, L., Wang, F., Lu, X., 2011. New insights into membrane fouling in a submerged anaerobic membrane bioreactor based on characterization of cake sludge and bulk sludge. Bioresource Technology 102, 2373-2379.

Lin, H., Zhang, M., Wang, F., Meng, F., Liao, B.-Q., Hong, H., Chen, J., Gao, W., 2014. A critical review of extracellular polymeric substances (EPSs) in membrane bioreactors: Characteristics, roles in membrane fouling and control strategies. Journal of Membrane Science 460, 110-125.

Lowry, O.H., Rosebrough, N.J., Farr, A.L., Randall, R.J., 1951. Protein measurement with the Folin phenol reagent. J biol Chem 193, 265-275.

Malaeb, L., Le-Clech, P., Vrouwenvelder, J.S., Ayoub, G.M., Saikaly, P.E., 2013. Do biological-based strategies hold promise to biofouling control in MBRs? Water research 47, 5447-5463.

Maqbool, T., Khan, S.J., Lee, C.-H., 2014. Effects of filtration modes on membrane fouling behavior and treatment in submerged membrane bioreactor. Bioresour. Technol. 172, 391-395.

Massé, A., Spérandio, M., Cabassud, C., 2006. Comparison of sludge characteristics and performance of a submerged membrane bioreactor and an activated sludge process at high solids retention time. Water Research 40, 2405-2415. 
Meng, F., Zhang, H., Yang, F., Li, Y., Xiao, J., Zhang, X., 2006. Effect of filamentous bacteria on membrane fouling in submerged membrane bioreactor. Journal of Membrane Science 272, 161-168.

Metcalf, L., Eddy, H., Tchobanoglous, G., 1991. Wastewater engineering: treatment, disposal, and reuse. McGraw-Hill, New York.

Mino, T., Van Loosdrecht, M., Heijnen, J., 1998. Microbiology and biochemistry of the enhanced biological phosphate removal process. Water research 32, 3193-3207.

Monclús, H., Sipma, J., Ferrero, G., Rodriguez-Roda, I., Comas, J., 2010. Biological nutrient removal in an MBR treating municipal wastewater with special focus on biological phosphorus removal. Bioresource technology 101, 3984-3991.

Nguyen, T.T., Ngo, H.H., Guo, W., 2013. Pilot scale study on a new membrane bioreactor hybrid system in municipal wastewater treatment. Bioresource technology 141, 8-12.

Peterson, G.L., 1977. A simplification of the protein assay method of Lowry et al. which is more generally applicable. Analytical biochemistry 83, 346-356.

Pochana, K., Keller, J., Lant, P., 1999. Model development for simultaneous nitrification and denitrification. Water Science and Technology 39, 235-243.

Puig, S., Coma, M., Monclús, H., Van Loosdrecht, M., Colprim, J., Balaguer, M., 2008. Selection between alcohols and volatile fatty acids as external carbon sources for EBPR. Water research 42, 557-566.

Sponza, D.T., 2002. Extracellular polymer substances and physicochemical properties of flocs in steady and unsteady-state activated sludge systems. Process Biochemistry 37, 983-998.

Wang, Y.-K., Pan, X.-R., Geng, Y.-K., Sheng, G.-P., 2015. Simultaneous effective carbon and nitrogen removals and phosphorus recovery in an intermittently aerated membrane bioreactor integrated system. Scientific reports 5 .

Wang, Z., Ma, J., Tang, C.Y., Kimura, K., Wang, Q., Han, X., 2014. Membrane cleaning in membrane bioreactors: a review. Journal of Membrane Science 468, 276-307.

Wu, J., Chen, F., Huang, X., Geng, W., Wen, X., 2006. Using inorganic coagulants to control membrane fouling in a submerged membrane bioreactor. Desalination 197, 124-136.

Wu, J., Le-Clech, P., Stuetz, R.M., Fane, A.G., Chen, V., 2008. Effects of relaxation and backwashing conditions on fouling in membrane bioreactor. Journal of Membrane Science 324, 26-32.

Yigit, N., Civelekoglu, G., Harman, I., Koseoglu, H., Kitis, M., 2010. Effects of various backwash scenarios on membrane fouling in a membrane bioreactor. Survival and Sustainability. Springer, pp. 917-929.

Zimmerman, J.B., Mihelcic, J.R., Smith, J., 2008. Global stressors on water quality and quantity. Environmental science \& technology 42, 4247-4254. 


\section{$\underline{\text { List of Tables }}$}

Table 1: Characteristics of screened raw wastewater

\begin{tabular}{lcc}
\hline \multicolumn{1}{c}{ Parameter } & Units & Screened raw water \\
\hline $\mathrm{pH}$ & - & $7.5 \pm 0.1$ \\
Total solids (TS) & $\mathrm{mg} / \mathrm{L}$ & $805 \pm 25$ \\
Total suspended solids (TSS) & $\mathrm{mg} / \mathrm{L}$ & $160.5 \pm 25.4$ \\
Biological oxygen demand (BOD 5$)$ & $\mathrm{mg} / \mathrm{L}$ & $262 \pm 43.7$ \\
Chemical oxygen demand $(\mathrm{COD})$ & $\mathrm{mg} / \mathrm{L}$ & $390.6 \pm 25.3$ \\
Ammonium nitrogen $\left(\mathrm{NH}_{4}{ }^{+}-\mathrm{N}\right)$ & $\mathrm{mg} / \mathrm{L}$ & $30.9 \pm 2.2$ \\
Total nitrogen $(\mathrm{TN})$ & $\mathrm{mg} / \mathrm{L}$ & $55.5 \pm 5.1$ \\
Total phosphorus $(\mathrm{TP})$ & $\mathrm{mg} / \mathrm{L}$ & $9.5 \pm 0.8$ \\
\hline
\end{tabular}

Table 2: Details of relaxation modes

\begin{tabular}{lccc}
\hline $\begin{array}{c}\text { Experiment } \\
\text { ID }\end{array}$ & $\begin{array}{c}\text { Filtration } \\
(\text { min) }\end{array}$ & $\begin{array}{c}\text { Operating Conditions } \\
\text { Relaxation } \\
(\text { min) }\end{array}$ & $\begin{array}{c}\text { Instantaneous Flux } \\
\text { (LMH) }\end{array}$ \\
\hline $\mathrm{MBR}_{10+0}$ & 10 & 0 & 12 \\
$\mathrm{MBR}_{10+1}$ & 10 & 1.0 & 13.5 \\
$\mathrm{MBR}_{10+1.5}$ & 10 & 1.5 & 14 \\
$\mathrm{MBR}_{10+2}$ & 10 & 2.0 & 15 \\
\hline
\end{tabular}


Table 3: Resistances of fouling fractions under different relaxation modes

\begin{tabular}{lcccc}
\hline \multicolumn{1}{c}{ Resistances $\left(\times \mathbf{1 0}^{\mathbf{1 2}}\right)$} & $\begin{array}{c}\mathbf{M B R}_{\mathbf{1 0 + 0}} \\
\left(\mathbf{m}^{\mathbf{- 1}}\right)\end{array}$ & $\begin{array}{c}\mathbf{M B R}_{\mathbf{1 0 + 1}} \\
\left(\mathbf{m}^{-\mathbf{1}}\right)\end{array}$ & $\begin{array}{c}\mathbf{M B R}_{\mathbf{1 0 + 1 . 5}} \\
\left(\mathbf{m}^{\mathbf{- 1}}\right)\end{array}$ & $\begin{array}{c}\mathbf{M B R}_{\mathbf{1 0 + 2}} \\
\left(\mathbf{m}^{-\mathbf{1}}\right)\end{array}$ \\
\hline Total hydraulic Resistance, $\mathrm{R}_{\mathrm{t}}$ & $5.92 \pm 0.75$ & $3.7 \pm 0.35$ & $3.3 \pm 0.25$ & $3.8 \pm 0.50$ \\
Cake layer resistance, $\mathrm{R}_{\mathrm{C}}$ & $3.32 \pm 0.25$ & $1.88 \pm 0.30$ & $1.5 \pm 0.27$ & $1.75 \pm 0.30$ \\
Pore blockage resistance, $\mathrm{R}_{\mathrm{P}}$ & $1.75 \pm 0.12$ & $1.1 \pm 0.21$ & $1.15 \pm 0.14$ & $1.2 \pm 0.25$ \\
Intrinsic membrane resistance, $\mathrm{R}_{\mathrm{M}}$ & $0.85 \pm 0.05$ & $0.80 \pm 0.04$ & $0.82 \pm 0.05$ & $0.86 \pm 0.08$ \\
$\mathrm{R}_{\mathrm{C}} / \mathrm{R}_{\mathrm{t}}(\%)$ & 56 & 50 & 45.5 & 46 \\
$\mathrm{R}_{\mathrm{P}} / \mathrm{R}_{\mathrm{t}}(\%)$ & 29.5 & 29.7 & 35 & 31.5 \\
\hline
\end{tabular}

Table 4: Average C/P ratio in SMP and eEPS

\begin{tabular}{lcc}
\hline \multicolumn{1}{c}{ Fractions } & SMP & eEPS \\
\hline Rinsed & 0.45 & 0.55 \\
Backwashed & 0.15 & - \\
Desorbed & 0.35 & - \\
Mixed Liquor & 0.49 & 0.55
\end{tabular}

Standard deviation was less than $10 \%$. 


\section{$\underline{\text { List of Figures }}$}

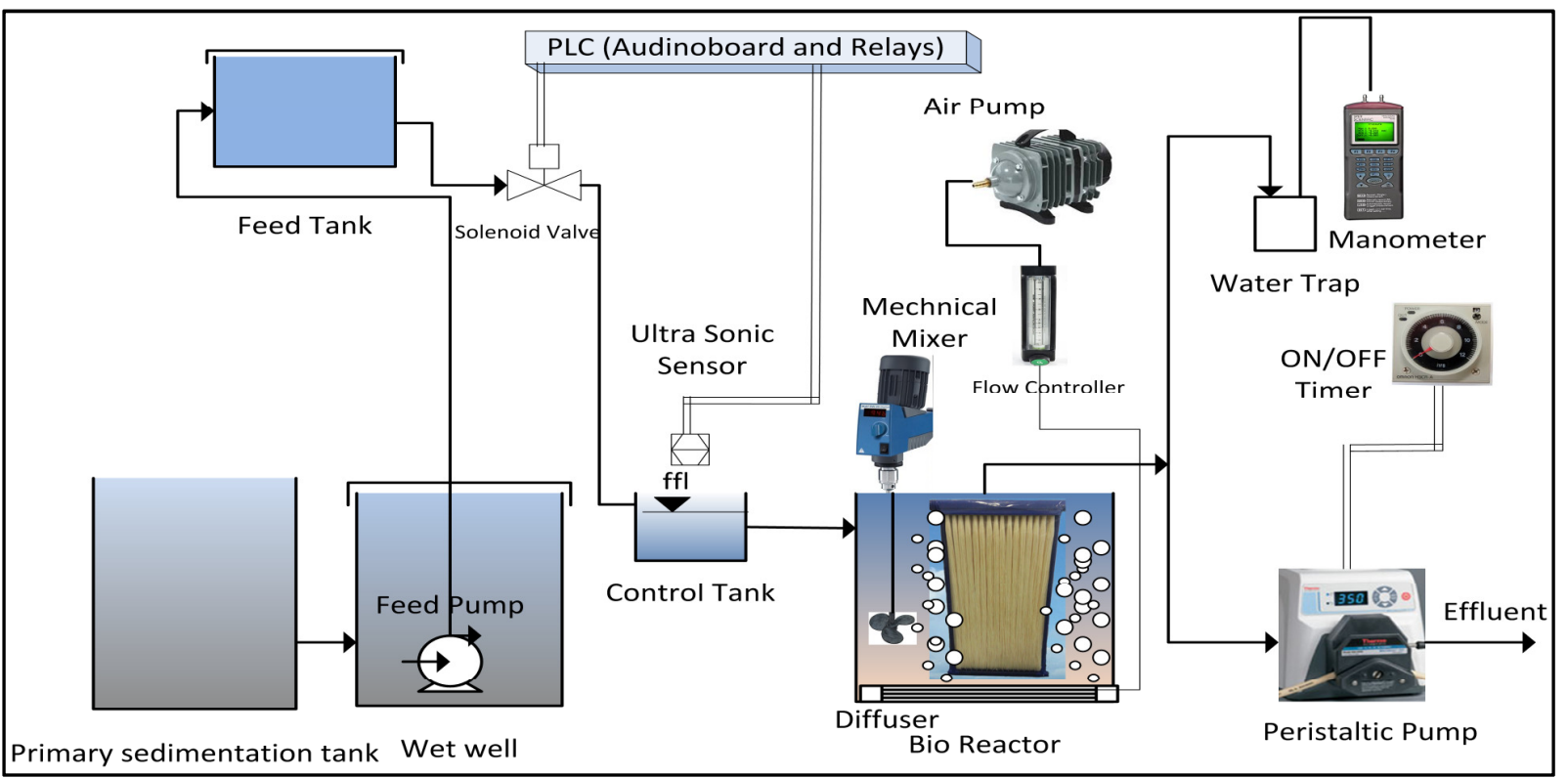

Fig 1: Schematics of Lab-scale MBR

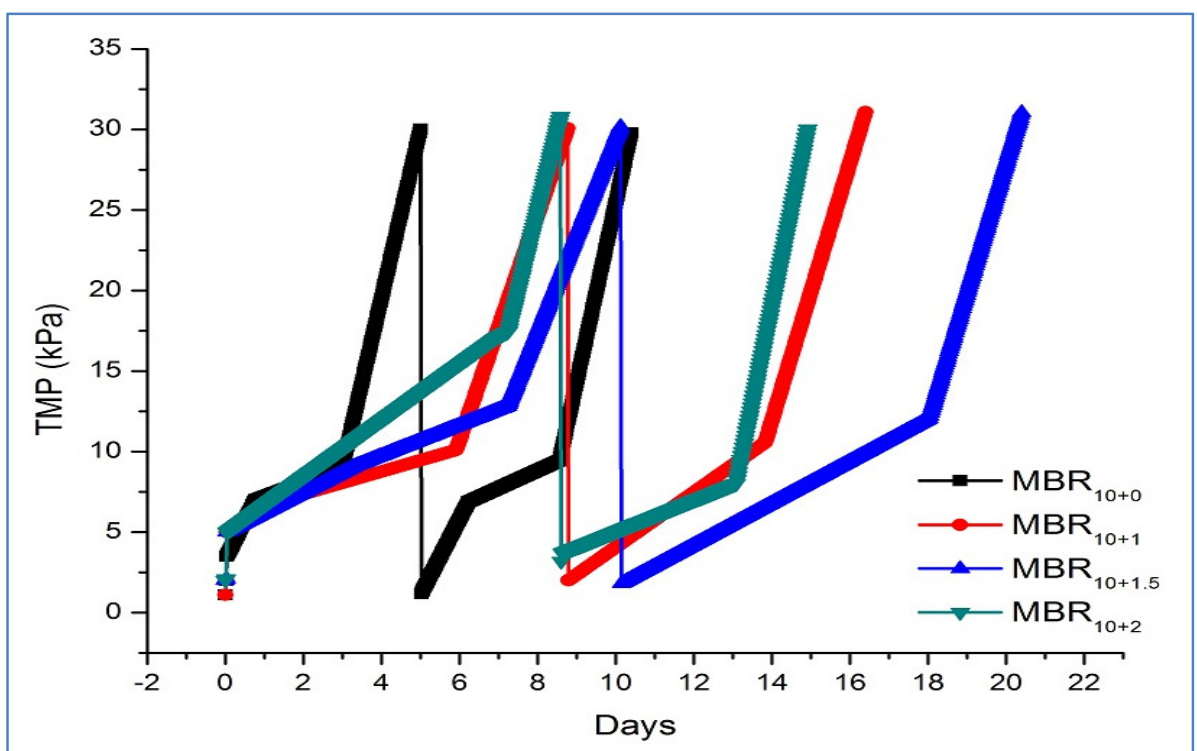

Fig 2: TMP profile for different relaxation modes 


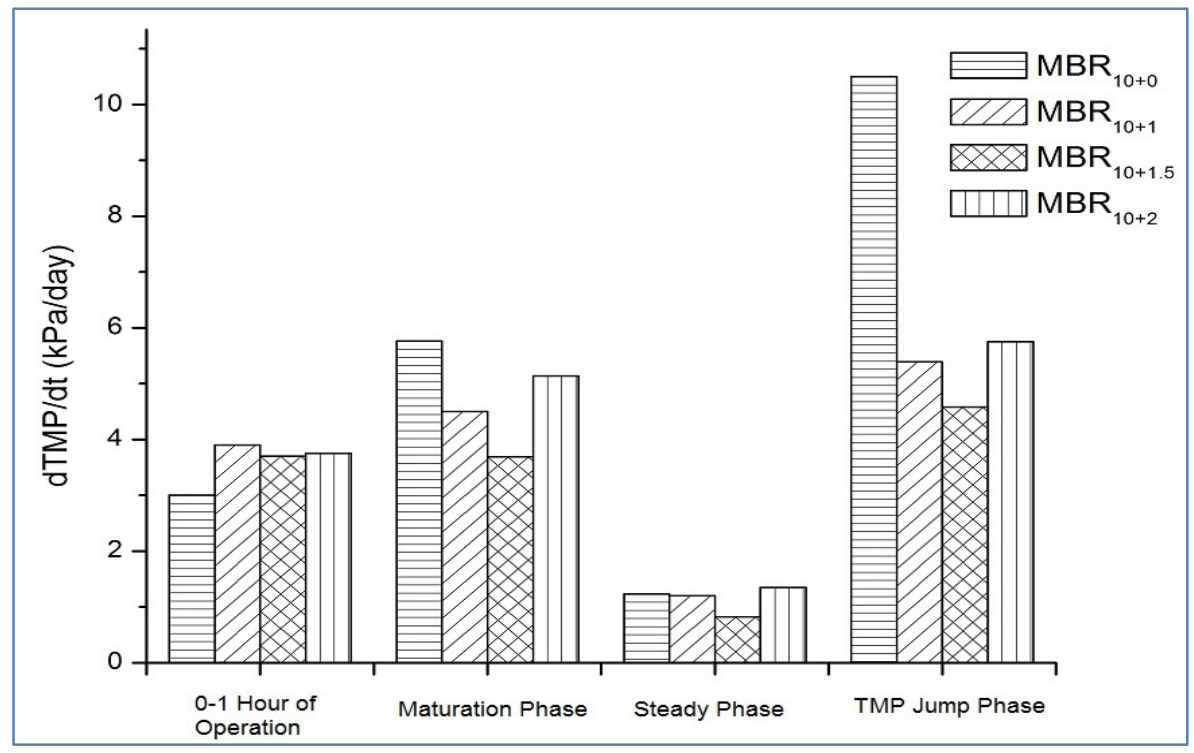

Fig 3: Temporal variations in fouling rates

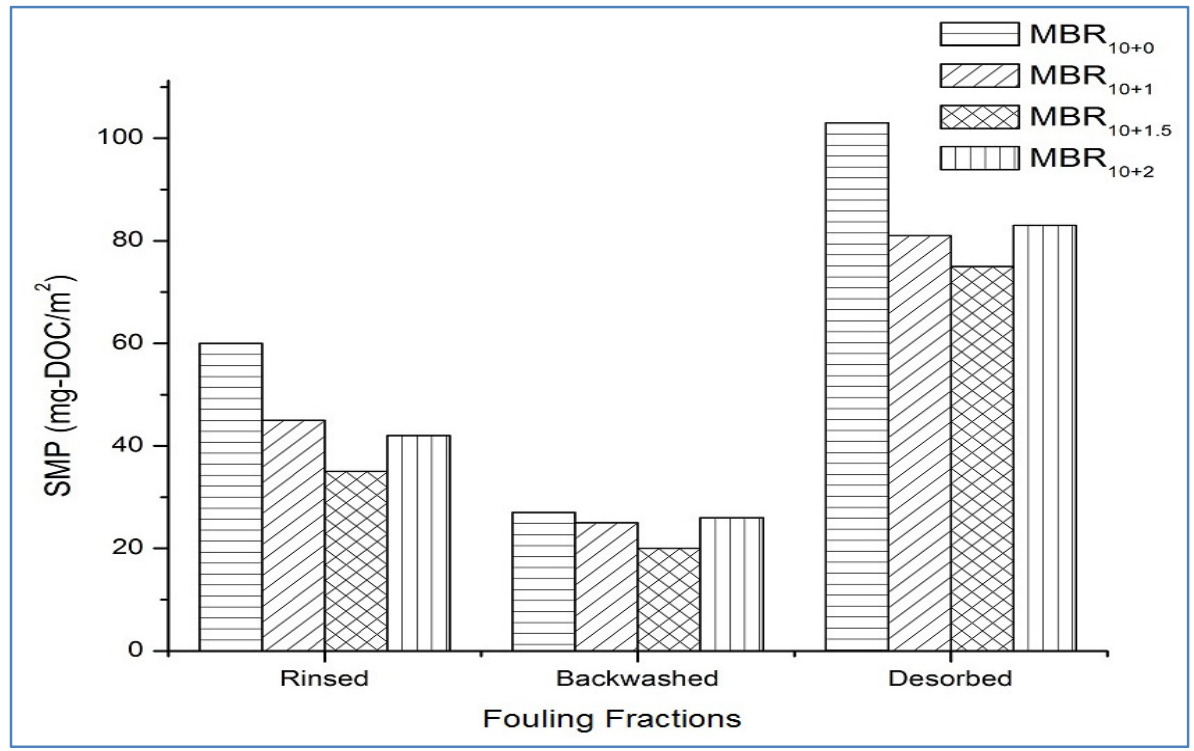

Fig 4: SMP profile for different fouling fractions 


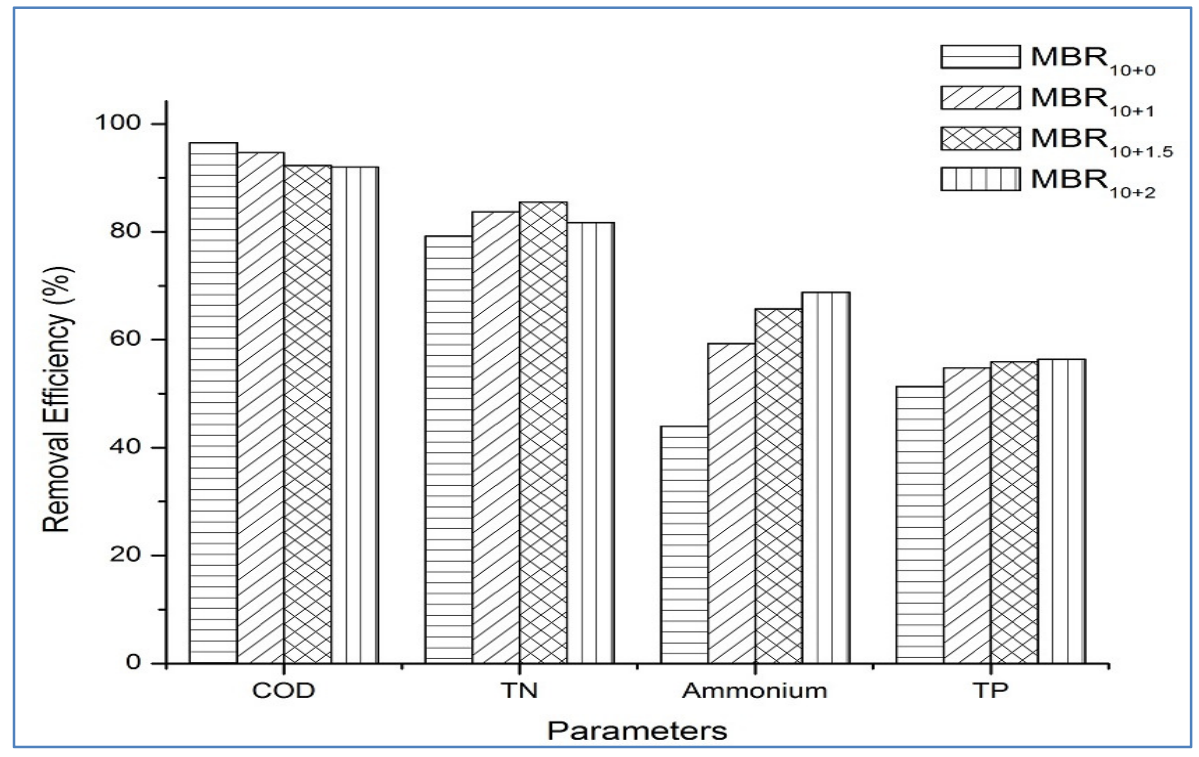

Fig.5: Treatment performance at different relaxation modes 